\title{
EFFECTS OF MAGNETIZED LOW QUALITY IRRIGATION WATER ON SOME SOIL PROPERTIES AND SOYBEAN YIELD (Glycine max L.) UNDER SALT AFFECTED SOILS CONDITIONS.
}

Amer, M. M.; A. G. El Sanat and Sahar H.. Rashed.

Soils, Water and Environment Research Institute, A R C.

\begin{abstract}
Two field experiments were conducted at Sakha Agric. Research Station, during two successive seasons 2013 and 2014, to study the effect of the magnetized water treatment (MWT) on some soil proprieties and productivity of soybean under salt affected soils conditions. A split plot design with three replicates was used. The main plots were occupied by water types (fresh water and magnetic irrigation water) and sub plots were devoted to water quality: $0.75 \mathrm{dSm}^{-1}\left(\mathrm{~S}_{1}\right), 1.75 \mathrm{dSm}^{-1}\left(\mathrm{~S}_{2}\right)$ and $2.75 \mathrm{dSm}^{-1}\left(\mathrm{~S}_{3}\right)$.

The obtained results could be summarized as follows:

- The growth parameters of soybean plants were high significantly increased due to application of the magnetic water.

- The soybean seed, straw and yield components were high significantly increased by magnetic water application under different water salinity.

-Protein and oil yields were high significantly increased by magnetized water treatment (MWT), while they were decreased with increasing of irrigation water salinity.

- The magnetic treatment of irrigation water had a positive effect on decreasing salinity of the soil $\left(E C_{e}\right)$ after the harvest of plants. Values of relative change $\left(\mathrm{Rc}_{ \pm} \%\right)$ of soil salinity $\left(E C_{e}\right)$, sodium adsorption ratio (SAR), $\mathrm{Na}^{+}, \mathrm{Cl}^{-}$and $\mathrm{SO}_{4}^{2-}$ were decreased while $\left(\mathrm{Rc}_{ \pm} \%\right)$ of $\mathrm{Ca}^{++}, \mathrm{Mg}^{++}$, and $\mathrm{K}^{+}$in the soil extraction , after harvesting, were increased due to MWT under $S_{1} ; S_{2}$ and $S_{3}$, as compared with magnetized fresh water .

-Yield of soybean, yield components, protein and oil yield content were positively correlated with (MWT) during both seasons.

-It could be concluded that to alleviate water salinity hazard, improve some soil properties and increase productivity of soybean plant can be obtained by magnetic water treatment under salt affected soil.

Keywords: salt affected soils, saline water, magnetic water treatment (MWT), soybean, and soils properties.
\end{abstract}

\section{INTRODUCTION}

Continuous use of saline irrigation water leads to soil salinization. High contents of soluble salts accumulated in the soil can significantly decrease the productivity of soils. Using poor quality irrigation water with high salinity is one of the main problems of agriculture in Egypt and many countries in the world. To reclaim soil and water, and to reduce soil salinity, magnetized water can be used (Kney and Parsons, 2006). Magnetized water is obtained by passing of water through the permanent magnets or through the electro magnets installed in/on a feed pipeline (Higashitani et al., 1993).

(Nasher, 2008) found that magnetized water has very affective effects on chick-pea., where its seeds production and plant length are increased 
noticeably. Treating water with static magnetic field increased its ability to solve soil solubility salts. Plants irrigated by magnetized water acquires more nutrients from soil.

The mechanism of the MTW activity in the soil is as yet unclear. There is a possibility that the effect is physical, viz. through a change in the solvent capacity. MTW increased yield parameters of crops like cereal, sunflower and soybean (Oldacay and Erdem; 2002).It has been established that the proper combination of magnetic field induction and exposure accelerates the early stages of plant development and improves the productivity. Consequently, the magnetic field effect can be used as an alternative to the chemical methods of plant treatment for improving the production efficiency (Aladjadjiyan and Ylieva; 2003). Mohamed and Ebead, (2013) studied the effect of irrigation with magnetically treated water on faba bean growth and composition in sandy soil and found that soil salinity, soluble cations and anions were significantly decreased. Hilal et al; (2002) reported that magnetized water was shown to have 3 main effects: 1) increasing the leaching of excess soluble salts, 2) lowering soil alkalinity and 3) dissolving slightly soluble salts such as carbonates, phosphates and sulfates. However, the degree of effectiveness of magnetized water on soil salinity and ionic balance in soil solution depended greatly on the traveling distance of magnetized water along the drip irrigation lines.

In general, the literature review revealed that there are possibly some beneficial effects of magnetic field on plant growth and other related parameters. However, there was no clarity as to the extent of these effects and mechanisms operating behind these effects. Furthermore, there is not much research carried out on the effects of magnetic treatment of irrigation water on plant growth and soil properties. In this study, therefore, the effects of magnetically treated fresh water, saline water and high saline irrigation water on soybean yield and some soil properties productivity were investigated under saline soil conditions. The main objectives of the study are:

- to examine the performance of magnetically treated fresh irrigation water, saline irrigation water and high saline irrigation water on growth and yield of soybean (Glycine max L."),

- to quantify protein and oil content of soybean as affected by magnetically treated irrigation water, and to determine the changes in soil properties due to irrigation with magnetically treated water under different level of irrigation water salinity.

\section{MATERIALS AND METHODS}

Two field experiments were conducted at the Experimental Farm, Sakha Agricultural Research Station, Kafr El-Sheikh Governorate, during the two successive summer growing seasons of 2013 and 2014. The site is located at $31^{\circ} 07 \mathrm{~N}$ latitude and $30^{\circ} 57 \mathrm{E}$ longitude with an elevation of about 6 meters above sea level. 
The experiments were designed as split plot with three replicates. As show in Fig.,1, The main plots were occupied by water types (fresh water and magnetic irrigation water) and sub plots were devoted to water quality :fresh water, $0.75 \mathrm{dsm}^{-1}\left(\mathrm{~S}_{1}\right), 1.75 \mathrm{dSm}^{-1}\left(\mathrm{~S}_{2}\right)$ and $2.75 \mathrm{dSm}^{-1}\left(\mathrm{~S}_{3}\right)$. The schematic of magnetic fields and direction of water flow during the magnetic treatment, are illustrated in Fig.(2)

\begin{tabular}{|c|c|c|c|c|c|c|c|c|c|c|}
\hline \multicolumn{11}{|c|}{ water pump } \\
\hline \multicolumn{5}{|c|}{ With magnetic } & \multirow[t]{2}{*}{$\underline{\Perp L}$} & \multicolumn{5}{|c|}{ Without magnetic } \\
\hline $\begin{array}{c}0.75 \\
\mathrm{dSm}^{-1}\end{array}$ & & $\begin{array}{c}1.75 \\
d^{-1} m^{-1}\end{array}$ & & $\begin{array}{c}2.75 \\
d^{-1} m^{-1}\end{array}$ & & $\begin{array}{c}0.75 \\
\mathrm{dSm}^{-1}\end{array}$ & & $\begin{array}{c}1.75 \\
d^{-1.1}\end{array}$ & & $2.75 \mathrm{dSm}^{-1}$ \\
\hline R1 & ह్ & R1 & ह్ & R1 & $\begin{array}{l}\text { हृ } \\
\text { 임 }\end{array}$ & R1 & ह్ & R1 & ह్ర్ & R1 \\
\hline $\mathbf{R 2}$ & $\mid \begin{array}{l}\mathbf{0} \\
\mathbf{N} \\
\mathbf{0}\end{array}$ & R2 & 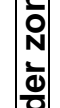 & $\mathbf{R 2}$ & $\begin{array}{l}\text { D } \\
\mathbf{N} \\
\frac{0}{0}\end{array}$ & $\mathbf{R 2}$ & 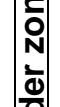 & $\mathbf{R 2}$ & $\mid$ & R2 \\
\hline R3 & m & R3 & Ф̊ & R3 & ○̊ & R3 & ๑̊ & R3 & 吕 & R3 \\
\hline
\end{tabular}

Fig.1:Layout of the experimental treatments in the field

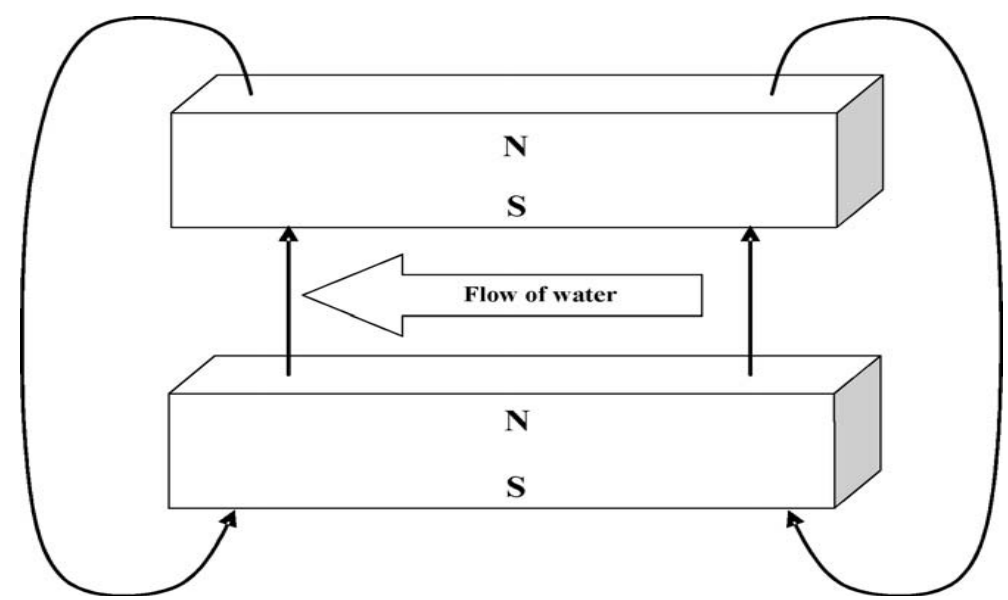

Fig. 2. Schematic of magnetic fields and direction of water flow during the magnetic treatment.

\section{Soil sampling and analysis:}

Soil samples ( $0-20,20-40$ and $40-60 \mathrm{~cm}$ depth) were collected before and after the treatments, and were analyzed for $\mathrm{pH}$ (in soil water suspension $1: 2.5$ ), EC (in soil paste extract at $25 \mathrm{C}^{\circ}$ ) . The bulk density was measured according to (Blake and Hartge, 1986). Particle size distribution was 
determined according to (piper,1950). Some chemical and physical characteristics of the studied soil are presented in Table (1)

\section{Plant analysis:}

At maturity, grains and straw yields of soybean (Glycine max L. cv. Giza 111) for each plot were measured. The yield components (number of pods plant $^{-1}$, no. of seeds plant ${ }^{-1}$, and 1000 seeds weight) for each treatment at each replicate were determined. The seed and straw samples were dried at $70 \mathrm{C}^{\circ}$ in a hot air oven. The dried samples were ground in the stainless steel Wiley Mill. The total $\mathrm{N}$ of soybean of ground dried seeds was determined by the micro-Kjeldahl method (Page et al. 1982). The $\mathrm{N}$ content was converted to protein content using the conversion factor of 5.71 (AOAC, 1975).Protein and oil yields for grain were calculated on a dry weight basis.

Table 1: Some chemical and physical characteristics for the studied soil (mean of both growing seasons).

\begin{tabular}{|c|c|c|c|c|c|c|c|c|c|c|c|c|c|c|c|c|}
\hline \multirow{2}{*}{$\begin{array}{l}\text { Soil } \\
\text { depth } \\
(\mathrm{cm})\end{array}$} & \multirow[t]{2}{*}{$\mathrm{pH}$} & \multirow{2}{*}{$\begin{array}{c}\mathrm{EC} \\
\mathrm{dSm}^{-1}\end{array}$} & \multirow{2}{*}{ SAR } & \multicolumn{4}{|c|}{$\begin{array}{l}\text { Soluble cations } \\
\left(\mathrm{Meq} \mathrm{L}^{-1}\right)\end{array}$} & \multicolumn{4}{|c|}{$\begin{array}{c}\text { Soluble anions } \\
\left(\mathrm{Meq} \mathrm{L}^{-1}\right)\end{array}$} & \multicolumn{3}{|c|}{$\begin{array}{l}\text { Particle size } \\
\text { distribution }\end{array}$} & \multirow{2}{*}{$\begin{array}{l}\text { Texture } \\
\text { class }\end{array}$} & \multirow{2}{*}{$\begin{array}{c}\text { Bulk } \\
\text { Density } \\
\left(\mathrm{kg} \mathrm{m}^{-3}\right)\end{array}$} \\
\hline & & & & & & $\mathrm{Na}^{+}$ & $\mathrm{K}^{+}$ & & & $\mathrm{Cl}^{-}$ & & $\underset{\%}{\text { Sand }}$ & \begin{tabular}{|c|} 
Silt \\
$\%$
\end{tabular} & $\begin{array}{c}\text { Clay } \\
\%\end{array}$ & & \\
\hline $0-20$ & 7.92 & 6.11 & 11.8 & 9.5 & 12.5 & 39.2 & 0.65 & 0.0 & 3 & 27.4 & 31.4 & 26.1 & 30.1 & 43.8 & & 20 \\
\hline $20-40$ & 7.96 & 6.91 & 12.8 & 10.7 & 13.9 & 44.9 & 0.69 & 0.0 & 3 & 31.4 & 35 & 25.6 & 30.3 & 44.1 & $\mathrm{Cla}$ & \\
\hline $40-60$ & 8.01 & 7.31 & 13.3 & 11.3 & 14.1 & 47.5 & 0.73 & 0.0 & 3.1 & 33.3 & 37.3 & 25.3 & 29.7 & 45 & Clayey & 1.39 \\
\hline Mean & 8.0 & 6.78 & 12.7 & 10.5 & 13.5 & 43.9 & 0.69 & 0.0 & 3.0 & 30.1 & 34.8 & 24.8 & 30.2 & 45 & Clayey & 1.3 \\
\hline
\end{tabular}

Data were analyzed statistically by a General Linear Model procedure and 2 way analysis of variance (ANOVA) using Cohort computer program according to the method of (Gomez and Gomez 1984). Mean separation procedure was performed using LSD's test at a 0.05 level of significance. Correlation analysis is used to determine the relations between the factors.

\section{RESULTS AND DISCUSSION}

\section{Soil properties after plant harvesting:}

The magnetic of irrigation water (MWT) had positive effect on decreasing salinity of the soil (ECe) after the harvesting of plants (Table, 2 and Fig., 3 ). Data show that mean values of relative change $\pm \%$ of $\left(E C_{e}\right)$ were decreased by about- $9.3 ;-7.4$ and $-8.7 \%$ for irrigation by fresh water; saline water and high saline water, respectively, also data indicate that the mean values of relative change $\pm \%$ of sodium adsorption ratio (SAR) were decreased by $-9.1 \%,-8.3 \%$, and $-11.5 \%$ with MWT as compared with un treated water UMWT. Data in Table 2 reveal also that relative changes ${ }_{ \pm} \%$ of EC and SAR were decreased with increasing the depth under different irrigation water salinity (Fig., 4). 12.7, 11.5, 10

Data in Table 2 clear that, mean relative change $\pm \%$ of concentration $\mathrm{Ca}^{2+}$ soluble cations of soil extract after harvesting was increased by about 2.6, 3.6 and 4.2 While $\mathrm{K}^{+}$was increased by about10,12.7 and 11.5 with magnetic; Fresh water, saline water and high saline water, respectively .On 
the other hand, data show that the mean relative change $\pm \%$ of cation Mg2+ was decreased by $2.9 \%, 6.2 \%$, and $8.7 \%$ with magnetized fresh water; saline water and high saline irrigation water, respectively, as compared with (UMWT)

Data in Table 2 and Fig. 5 refer that the mean values of relative change $\pm \%$ of $\mathrm{Na}^{+}$were decreased by $-9.2 \%,-9.2 \%$, and $-13.1 \%$, while the mean relative change $\pm \%$ of $\mathrm{Cl}^{-}$were decreased by $-10.5 \%,-9.2 \%$, and $-13.7 \%$ with magnetized fresh water; saline water and high saline water, respectively. compared MWT with UMWT (Fig., 6).

On the other hand, data in Table (2) and Fig., (7) refer that the mean values of relative change $\pm \%$ of $\mathrm{SO}^{-2}{ }_{4}$ were decreased by $-2.2 \%,-4.2 \%$, and $-5.8 \%$ for magnetized water with salinity of $S_{1} ; S_{2}$ and $S_{3}$, respectively. as compared with (UMWT) .

The results of this study show that magnetized water plays an important role in salts soluble salts resulting in increasing their removal from the soil. Removal of excess salts or decreasing their activity is necessary for increasing the productivity of salt affected soils., on this respect, Hilal et al., (2002) stated that magnetized water increases the leaching of excess soluble salts, lower soil alkalinity, and dissolve low soluble salts such as carbonates, phosphates and sulfates.

Table ( 2) : Relative change ( $\pm \%$ ) of some chemical characteristics of the soil after harvesting of soybean as affected by irrigation by magnetized low quality water. (mean of both growing seasons)

\begin{tabular}{|c|c|c|c|c|c|c|c|c|c|c|c|}
\hline \multirow{2}{*}{$\begin{array}{l}\text { Irrigation } \\
\text { Water } \\
\text { Salinity }\left(\mathrm{dSm}^{-1}\right)\end{array}$} & \multirow{2}{*}{$\begin{array}{l}\text { Depth } \\
(\mathrm{cm})\end{array}$} & \multirow{2}{*}{$\begin{array}{c}\mathrm{EC} \\
\mathrm{dSm}^{-1}\end{array}$} & \multirow{2}{*}{$\begin{array}{c}\text { SAR } \\
(\%)\end{array}$} & \multicolumn{4}{|c|}{ Cations } & \multicolumn{4}{|c|}{ Anions } \\
\hline & & & & $\mathrm{Ca}^{2+}$ & $\mathrm{Mg}^{2+}$ & $\mathrm{Na}^{+}$ & $\mathrm{K}^{+}$ & $\mathrm{CO}^{3}$ & $\mathrm{HCO}^{-3}$ & $\mathrm{Cl}^{-}$ & SO $^{-4}$ \\
\hline \multirow{4}{*}{0.75} & $0-20$ & -3.8 & -8.6 & 6.7 & -1.2 & -7.1 & 12.9 & 0.0 & -3.6 & -7.1 & -0.1 \\
\hline & $20-40$ & -11.6 & -12.4 & 5.3 & -8.4 & -13.5 & 9.2 & 0.0 & -3.6 & -14.3 & -5.1 \\
\hline & $40-60$ & -12.4 & -8.8 & 7.6 & -17.8 & -12.0 & 10.1 & 0.0 & -3.3 & -12.7 & -7.1 \\
\hline & Mean & \begin{tabular}{|l|}
-9.3 \\
\end{tabular} & -9.1 & 2.6 & -2.9 & -9.2 & 10.0 & 0.0 & -1.7 & -10.5 & -2.2 \\
\hline \multirow{4}{*}{1.75} & $0-20$ & -8.8 & -9.0 & 4.5 & -13.0 & -11.5 & 11.3 & 0.0 & 0.0 & -11.5 & -7.1 \\
\hline & $20-40$ & -8.6 & -6.6 & 4.0 & -4.3 & -6.9 & 15.3 & 0.0 & 0.0 & -6.2 & -3.1 \\
\hline & $40-60$ & -4.7 & -7.8 & 4.0 & -5.3 & -8.3 & 11.7 & 0.0 & 0.0 & -8.3 & -3.4 \\
\hline & Mean & -7.4 & -8.3 & 3.6 & -6.2 & -9.2 & 12.7 & 0.0 & 0.0 & -9.2 & -4.2 \\
\hline \multirow{4}{*}{2.75} & $0-20$ & -14.1 & -16.4 & 4.8 & -14.1 & -19.4 & 8.2 & 0.0 & 0.0 & -20.3 & -9.5 \\
\hline & $20-40$ & -6.4 & -9.5 & 3.9 & -6.4 & -10.4 & 12.9 & 0.0 & -7.1 & -10.4 & -4.2 \\
\hline & $40-60$ & -5.6 & -8.6 & 3.9 & -5.6 & -9.4 & 13.4 & 0.0 & 6.7 & -10.2 & -3.8 \\
\hline & Mean & -8.7 & -11.5 & 4.2 & -8.7 & -13.1 & 11.5 & 0.0 & -0.2 & -13.7 & -5.8 \\
\hline
\end{tabular}


Amer, M. M. et al.

Fig.(3): Effects of magnetized low quality irrigation water on EC of soil after harvesting of soybean. (mean of both growing seasons)

Fig. (4 ): Effects of magnetized low quality irrigation water on SAR (\%) of soil after harvesting of soybean . (mean of both growing seasons) 
Fig.(5 ): Effects of magnetized low quality irrigation water on $\mathrm{Na}^{+}(\mathrm{meq} / \mathrm{l})$ of soil after harvesting of soybean. (mean of both growing seasons)

Fig.(6): Effects of magnetized low quality irrigation water on $\mathrm{Cl}^{-}$(meq/l) of soil after harvesting of soybean. (mean of both growing seasons) 
Fig.(7 ): Effects of magnetized low quality irrigation water on $\mathrm{SO}^{-}$ (meq/l) of soil after harvesting. (mean of both growing seasons)

\section{Yield of soybean and attributed growth:}

With respect to the effect of MWT on seed and straw yields of soybean, data presented in Table (3) point out that seed and straw yields of soybean were highly significantly increased due to MWT as compared to UMWT during both growing seasons.

Data also, point out that irrigation of soybean plant by MWT increased significantly the growth parameters (1000 seed weight, no of pods/ plant, no of branch/plant, seeds weight/plant, weight of pods/plant as compared to untreated plants. These results are correspondence with that obtained by Morejon, et al. ,(2007). Hilal and Hilal, (2000) who reported that magnetized water has more tripled seedling emergence of wheat than tap water. Renia, et al., (2001) found significance increase in the rate of water absorption accompanied with an increase in total mass of lettuce with the increase of magnetic force. Moreover, Nasher, (2008) found that chick pea plants irrigated by magnetized water were taller than plants irrigated with tap water. Also, significant increases in pigment fractions were recorded in chickpea plants irrigated by magnetized water .

Data in Table (3) show also that seed and straw yield of soybean were highly significant decreased by increasing salinity of irrigation water where the lowest value obtained by salinity level $\mathrm{S}_{3}$. 
Data in Table (3) illustrate that yield of soybean was high significantly due to the interaction between salinity of the irrigation water and magnetized water treatment (MWT) during both growing seasons.

Table (3) : Main effects of irrigation by magnetized low quality water on yield of soybean under saline soil conditions. (mean of both growing seasons)

\begin{tabular}{|c|c|c|c|c|c|c|c|}
\hline Yield & $\begin{array}{l}\text { Seed } \\
\text { (t/fed.) }\end{array}$ & $\begin{array}{l}\text { Straw } \\
\text { (t/fed.) }\end{array}$ & $\begin{array}{c}1000 \\
\text { seed } \\
\text { weight } \\
\text { (g) }\end{array}$ & $\begin{array}{c}\text { No.pods/ } \\
\text { plant }\end{array}$ & $\begin{array}{l}\text { No. } \\
\text { branch } \\
\text { / plant }\end{array}$ & $\begin{array}{l}\text { Seeds/ } \\
\text { plant }(g)\end{array}$ & $\begin{array}{c}\text { Weight } \\
\text { Pods/plant }\end{array}$ \\
\hline \multicolumn{8}{|c|}{ Magnetic (M) } \\
\hline without & $1.003 \mathrm{~b}$ & $2.109 \mathrm{~b}$ & $18.05 b$ & $54.44 \mathrm{~b}$ & $3.0 \mathrm{~b}$ & $18.89 \mathrm{~b}$ & $30.9 b$ \\
\hline \begin{tabular}{|l|} 
with \\
\end{tabular} & $1.360 \mathrm{a}$ & $2.438 \mathrm{a}$ & $20.49 a$ & $67.44 a$ & $5.0 \mathrm{a}$ & $21.88 a$ & $38.72 a$ \\
\hline $\mathrm{F}_{\text {test }}$ & $\star *$ & ** & $\star *$ & $\star *$ & $\star *$ & ** & $\star *$ \\
\hline $\operatorname{LSD}_{0.05}$ & 0.019 & 0.06 & 0.24 & 1.43 & 0.82 & 0.385 & 0.29 \\
\hline $\mathrm{LSD}_{0.01}$ & 0.045 & 0.139 & 0.566 & 3.30 & 1.91 & 0.890 & 0.67 \\
\hline \multicolumn{8}{|c|}{ Water Salinity (S) } \\
\hline $0.75 \mathrm{dSm}^{-1}$ & $1.326 \mathrm{a}$ & $2.42 \mathrm{a}$ & $19.99 a$ & $67.0 \mathrm{a}$ & $4.66 \mathrm{a}$ & $21.40 \mathrm{a}$ & $37.08 \mathrm{a}$ \\
\hline $1.75 \mathrm{dSm}^{-1}$ & $1.149 \mathrm{~b}$ & $2.305 b$ & $19.32 b$ & $62.0 \mathrm{~b}$ & $4.0 \mathrm{~b}$ & $20.29 \mathrm{~b}$ & $39.93 b$ \\
\hline $2.75 \mathrm{dSm}^{-1}$ & $1.07 \mathrm{c}$ & $2.096 \mathrm{c}$ & $18.51 \mathrm{c}$ & $53.83 \mathrm{c}$ & $3.33 \mathrm{c}$ & $19.16 \mathrm{c}$ & $32.42 \mathrm{c}$ \\
\hline$F_{\text {test }}$ & ** & $\star \star *$ & $\star \star *$ & ** & $\star \star *$ & $\star *$ & $* *$ \\
\hline $\mathrm{LSD}_{0.05}$ & 0.031 & 0.035 & 0.211 & 0.58 & 0.38 & 0.11 & 0.93 \\
\hline $\mathrm{LSD}_{0.01}$ & 0.046 & 0.051 & 0.30 & 0.85 & 0.55 & 0.160 & 1.36 \\
\hline \multicolumn{8}{|c|}{ Interaction } \\
\hline $\mathrm{M}^{*} \mathrm{~S}$ & ** & ** & ** & ** & * & ** & ns \\
\hline
\end{tabular}

Protein and oil yield content:-

Data in Table (4) point out that the yield and content of protein and oil were high significantly increased with MWT in both growing seasons. On the other hand, protein and oil yield and contents and plant height were high significantly decreased as salinity of irrigation water increased. Where the highest values were recorded with fresh water $\left(0.75 \mathrm{dSm}^{-1}\right)$ and the lowest values were recorded with saline water $\left(2.75 \mathrm{dSm}^{-1}\right)$.

The data reveal that protein yield of soybean was insignificantly affected by the interaction between salinity and magnetic treatment of irrigation water during both growing seasons, while oil yield was high significantly affected by the interaction. 
Table (4) : Effects of magnetized low quality irrigation water on protein and oil yields, and plant height, (mean of both growing seasons)

\begin{tabular}{|c|c|c|c|c|c|}
\hline $\begin{array}{l}\text { Yield } \\
\text { Treat. }\end{array}$ & $\begin{array}{l}\text { protein } \\
(\%)\end{array}$ & $\begin{array}{l}\text { protein yield } \\
\text { kgFed. }^{-1}\end{array}$ & Oil (\%) & $\begin{array}{l}\text { oil yield } \\
\text { kgFed. }^{-1}\end{array}$ & $\begin{array}{l}\text { plant height } \\
\text { (cm) }\end{array}$ \\
\hline \multicolumn{6}{|c|}{ Magnetic (M) } \\
\hline Without & $38.12 b$ & $383.69 b$ & $20.94 b$ & $210.94 b$ & $92.33 b$ \\
\hline With & $41.68 \mathrm{a}$ & $567.99 a$ & $23.52 a$ & $320.42 a$ & $114.77 a$ \\
\hline$F_{\text {test }}$ & $* *$ & ** & $* *$ & ** & ** \\
\hline $\mathrm{LSD}_{0.05}$ & 0.565 & 14.07 & 0.12 & 4.96 & 0.47 \\
\hline $\mathrm{LSD}_{0.01}$ & 1.303 & 32.45 & 0.28 & 11.46 & 1.10 \\
\hline \multicolumn{6}{|c|}{ Water Salinity (S) } \\
\hline $\begin{array}{c}0.75 \\
\mathrm{dSm}^{-1}\end{array}$ & $41.1 \mathrm{a}$ & $547.95 a$ & $22.88 a$ & $305.43 a$ & $109.66 a$ \\
\hline $\begin{array}{c}1.75 \\
d^{-1} m^{-1}\end{array}$ & $39.74 b$ & $459.93 b$ & $22.18 b$ & $256.93 b$ & 103.83b \\
\hline $\begin{array}{c}2.75 \\
\mathrm{dSm}^{-1}\end{array}$ & $38.88 \mathrm{c}$ & 419.637c & $21.63 c$ & $234.68 c$ & $97.16 \mathrm{c}$ \\
\hline $\mathrm{F}_{\text {test }}$ & ${ }^{* *}$ & ** & $\star *$ & $\star * *$ & ** \\
\hline $\mathrm{LSD}_{0.05}$ & 0.226 & 12.45 & 0.17 & 7.96 & 1.25 \\
\hline $\mathrm{LSD}_{0.01}$ & 0.33 & 18.12 & 0.24 & 14.03 & 1.82 \\
\hline$M * S$ & ns & $\mathrm{ns}$ & 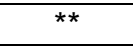 & ** & ** \\
\hline
\end{tabular}

Table (5 ): Correlation coefficient between magnetic , water salinity, yield and yield components of soybean.

\begin{tabular}{|l|c|c|}
\hline $\begin{array}{l}\text { Rat } \\
\text { Significant at 0.05 }\end{array}$ & Magnetic & Water salinity \\
\hline Seed (t/fed.) & $0.85^{* *}$ & $-0.49^{*}$ \\
\hline Straw (t/fed.) & $0.74^{* *}$ & $-0.59^{* *}$ \\
\hline 1000 seed weight (g) & $0.87^{* *}$ & $-0.43 \mathrm{~ns}$ \\
\hline No. Pods/plant & $0.75^{* *}$ & $-0.62 \mathrm{~ns}$ \\
\hline No. Branch/plant & $0.83^{* *}$ & $-0.45 \mathrm{~ns}$ \\
\hline Seeds/plant g & $0.83^{* *}$ & $-0.48^{*}$ \\
\hline Plant height (cm) & $0.90^{* *}$ & $-0.41 \mathrm{~ns}$ \\
\hline yield protein & $0.86^{* *}$ & $-0.48^{*}$ \\
\hline yield oil & $0.87^{* *}$ & $-0.46 \mathrm{~ns}$ \\
\hline Protein (\%) & $0.88^{* *}$ & $-0.45 \mathrm{~ns}$ \\
\hline Oil (\%) & $0.91^{* *}$ & $-0.36 \mathrm{~ns}$ \\
\hline
\end{tabular}

Correlation coefficient by magnetic treatment , water salinity, yield and yield components of soybean.

The results listed in Table (5) point out that soybean yield and its components, protein and oil contents have strong positive correlation coefficient due MWT in both growing seasons. Also, data show that there are weak significant opposite correlation coefficient between seed and salinity of 
irrigation water, while highly significant, strong opposite correlation coefficient was found between straw and salinity of irrigation water. On the other side, insignificant, strong opposite correlation coefficient was observed between No. of pods/plant and salinity of irrigation water, while insignificant weak opposite correlation coefficient was found between both of yield of oil, protein, 1000-seed weight, No. of branch/plant and salinity of irrigation water.

\section{CONCLUSION}

Yield and yield components of soybean, protein and oil yield and contents were high significantly increased and positive strongly correlated with magnetized irrigation water treatment.

Magnetized irrigation water alleviated the bad effect of water salinity, minimized soil salinity and improved some soil properties and productivity under salt affected soils in North Delta.

\section{Acknowledgements}

Deep gratitude and sincere thanks to Prof.Dr M.I. El-Shahawy (Head of Researches) for his continuous encouragement and providing facilities to carry out this work My great thanks are also to Prof.Dr. Kamal Halil (Head of Researches) Soil, Water and Environment Res. For sincere help through this work.

\section{REFERENCES}

Aladjadjiyan, A. and Ylieva, T. (2003). Influence of stationary magnetic field on the early stages of the development of tobacco seeds (Nicotianatabacum L.).J.of Central European Agric 132,4 (2): 131-138.

AOAC, (1975). (Association of Official Agricultural Chemists). Official methods of analysis 12th ed. Washington, D.C. USA.

Blake, G.R. and Hartge, K.H. (1986). Bulk Density," In: A. Klute, et al., Eds., Methods of Soil Analysis, Part I, ASA

Gomez, K.A.and Gomez, A.A. (1984). Statistical procedures for agricultural research, 2nd edition. John Wiley and Sons, New York, 680.

Higashitani, K.; Kage, A., Katamura, S., Imai, K. and Hatade, S. (1993).Effects of a magnetic field on the formation of $\mathrm{CaCO}_{3}$ particles. Colloid and Interface Science., 156 (1): 90-95.

Hilal, M.H. and Hillal, M.M. (2000). Application of magnetic technologies in desert agriculture .1-Seed germination and seedling emergence of some crop in a saline calcareous soil. Egypt J. Soil Sci.40:(3), 413-421.

Hilal, M.H., Shata, S.M.; Abdel- Dayem, A.A. and Hillal, M.M. (2002).Application of magnetic technologies in desert agriculture. IIIEffect of Magnetized Water on yield and uptake of certain elements by citrus in relation to nutrients mobilization in soil. Egypt J. Soil Sci. 42(1), 43-55.

Kney, A. D., and Parsons, S. A.(2006). A spectrophotometer-based study of magnetic water treatment: Assessment of ionic vs. surface mechanisms. Water Research, 40 (3): 517-524.

Mohamed, A. I. and Ebead, B. M.(2013). Effect of irrigation with magnetically treated water on faba bean growth and composition. International J. of Agric.Policy and Res. 1 (2), 024-040. 
Morejon, L.P, Castro J.C., Velazquez, L.G. and Govea, A.P. (2007), Simulation of pinus tropicalis seeds by magnetically treated water. Int. Agrophys.;21:173-177.

Nasher, S.H. (2008). The Effect of magnetic water on growth of chick-pea seeds Eng. \& Tech. 26,(9):4.

Oldacay, S and Erdem, G. (2002). Evaluation of chlorophyll contents and peroxides activities in (Helianthusannuus L.) genotypes exposed to radiation and magnetic field. Pakistan J. of Applied Sci.2(10): 934-937

Page, A.L.R.; Miller, H. and Keeney, D.R. (1982). Methods of Soil Analysis. Part 2: Chemical and Microbiological Properties. 2nd Edition, Agronomy Monograph, no. 9, ASA, CSSA, and SSSA, Madison.

Piper, C.S., (1950). Soil and Plant Analysis. Inter science Publication. New York. Reddy, B.V.S; Reddy, P.S., Bidinger, F.

Reina, F.G., Pascual, L.A. and Fundora, I.A. (2001). Influence of a stationary magnetic field on water relations in lettuce seeds. Part II: Experimental Results. Bio electromagnetic. ;22:596-602.

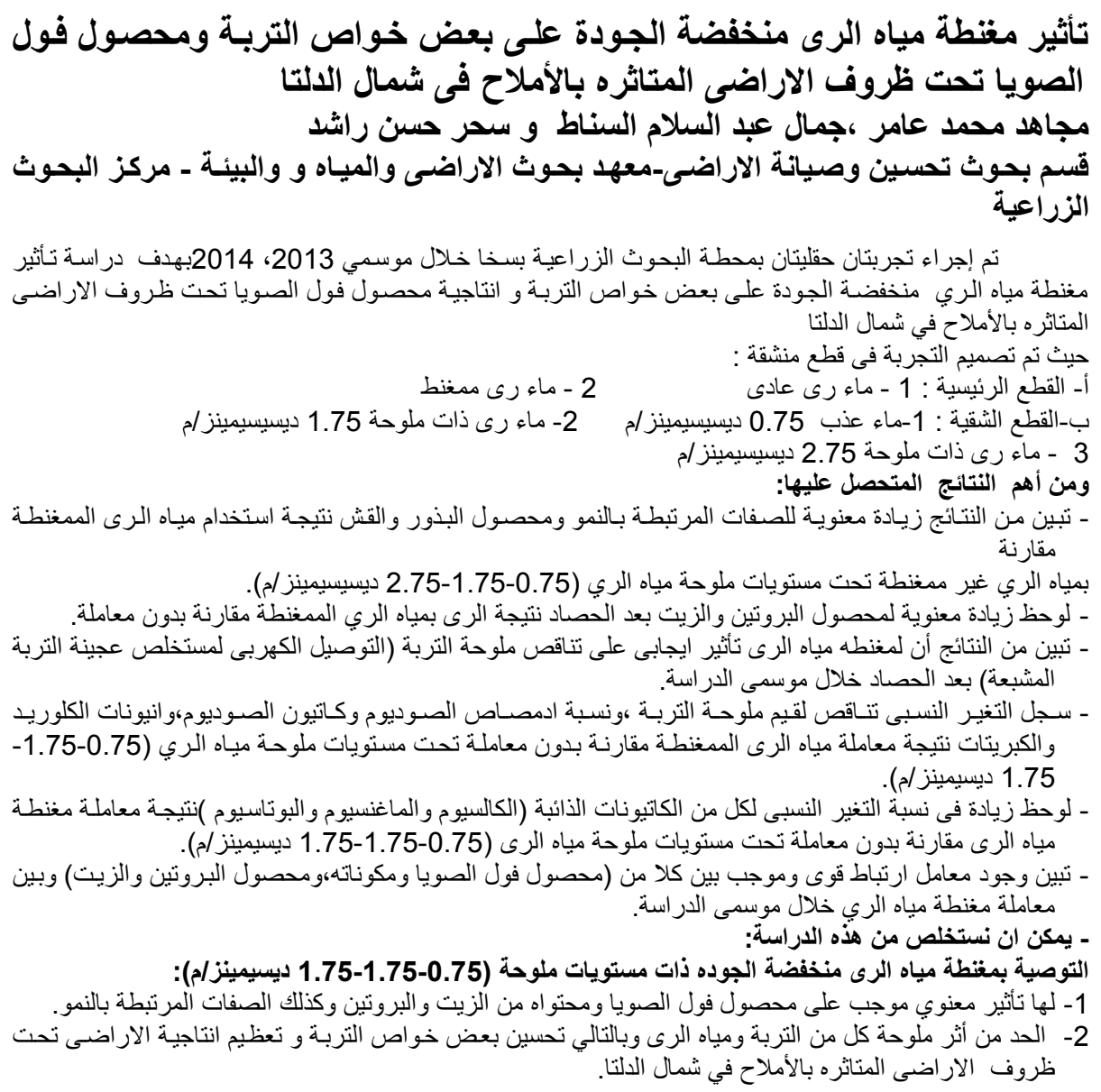

